\section{PROGRESS OF GEOLOGY IN THE U.S.S.R.}

COVIET writers have good cause for satisfaction $S$ in the achievements of their country in the field of geology since the Revolution of 1917. This justifiable self-satisfaction has a less justifiable corollary in the constant emphasis on the backwardness of pre-Revolutionary Russia. The pace of scientific progress has increased everywhere in the last few decades, both from its own momentum and because of the vast increase in the number of workers in the field ; but this should not detract from our apprecia. tion of the worth of earlier patrons and scholars working in less favourable circumstances.

Russia could boast a mineralogical museum, of a sort, as early as 1716. It was founded by Peter the Great, who was also responsible for the start of a systematic survey of the Russian Empire. By the middle of the century, the great Russian scientific worker M. V. Lomonosov (1711-65) was actively engaged in geological work, and later in the same century, in 1773-a date at which no similar institution existed in Great Britain-the Mining Institute of St. Petersburg was founded. It is true that in the eighteenth century and even later the bulk of the geological work in Russia was carried out by foreigners, among whom the name of Sir Robert Murchison is outstanding. Gradually, however, the Russian geologists asserted themselves and a number of them achieved recognition in the international sphere. Such were A. A. Inostranzev, I. V. Mushketov, M. V. Pavlov, A. P. Karpinsky, E. S. Fedorov, F. Y. Loewinson-Lessing and many others. It is claimed, however, that the progress made during the past twenty-five years exceeds by far all previous achievements. 'This is probably true, if one considers the scale of the geological research and the number of workers engaged. It is estimated that in 1914 no more than three hundred professional geologists existed in Russia, and that vast territories such as Siberia, Central Asia and the Caucasus were served by only a handful of men. Although it is impossible to estimate the present numbers engaged in geological work in the U.S.S.R., it must be at least ten times as large. At the last International Geological Congress held in Moscow in 1937, the Russian membership exceeded 1,500 members, and this figure did not include many junior workers.

This Congress and the recently published book ${ }^{1}$, which is the main subject of this review, must be taken together as an attempt to make widely known the results of a quarter of a century of endeavour in the field of geology (and the kindred sciences of mineralogy and petrology) and the stages by which those results were achieved. The Congress aimed mainly at the enlightenment of non-Russian men of science; on those who were fortunate enough to be present in Moscow and on the elaborate field excursions it will leave an indelible impression. For those who have no such personal recollections, the guidebooks and published abstracts of papers provide no adequate substitute. On the other hand, the collection of twenty-five articles on the various branches of geology which comprise the "Progress of Geological and Geographical Sciences in the U.S.S.R. during Twenty-five Years" are very full and well documented, but they are in Russian.

Each article is the work of a prominent authority on its subject, and the whole collection is edited by the veteran Russian geologist V. A. Obruchev. All branches of geology are represented (including one article on geography) with the exception of palæophytology and the regional geology of European Russia, which are missing. because the War has absorbed the energies and the time of the men who were to have been responsible for them. It is impossible in this review to give an adequate exposition of the book, but it may be useful to indicate some of its most important points.

First come the articles dealing with the progress made in mineralogy and petrology. These are very informative and they provide a good account of the work of different research schools, such as that on crystal optics originated by E. S. Fedorov, physicochemical analysis by N. S. Kurnakov, mineral synthesis by D. P. Grigoriev and geochemistry by V. I. Vernadsky and A. E. Fersman. In petrology, naturally, the name of F. Y. Loewinson-Lessing comes first, but much has been achieved by many other petrologists - D. S. Belyankin, B. M. Kupletsky, V. N. Lodochnikov, A. N. Zavarizky and others. The Petrographical Institute founded in 1931 is in a way unique in the whole world, and in the short period of its existence has published, besides the periodical Travaux de l'Institut Petrographique, a great number of monographs on the regional petrography of the U.S.S.R., on various rocks and rock-forming minerals. Technical petrology is also extremely well developed in the U.S.S.R., and a number of workers are engaged on the study of slags, cements, fire-resisting materials, glass and cast basalt.

The articles dealing with the progress of palæontology are rather short. On the other hand, those on stratigraphy are the longest and the most valuable of the book. The industrial prospecting for coal, oil and bedded ores is no doubt partly responsible for the progress made in these branches of geology, and it is significant that the greatest amount of work has been done in the study of Carboniferous and Tertiary rocks, the main sources of coal and oil. This does not preclude the achievement made in the study of other systems, and geological mapping and surveying is constantly on the increase all over the territory of the U.S.S.R., but more particularly in the Urals, Siberia, Central Asia and the Caucasus. During this new survey, many startling discoveries have been made, discoveries which have often led to a complete revision of previously accepted knowledge. Stratigraphical work nearly always involves tectonics, and the technique of tectonic investigation recently developed in western Europe and the United States has been applied with the greatest effect by Russian workers. The major tectonic problems, sometimes called geotectonics, have received a good deal of attention, and as so often happens have become involved in a tangle of conflicting hypotheses of a highly speculative nature. For example, a well-known Russian geologist, M. M. Tetiaev, raised a storm recently by a hypothesis which postulates that the tectonic move ments are mainly due to the expansion of the earth's interior, and that the folded mountains are due to the pressure exercised by the expanding core against the rigid earth's crust. Many other tectonic hypotheses have been proposed and demolished.

The remaining articles deal with the progress made in engineering geology, applied geophysics, the study of permanently frozen ground, the study of coal, oil shales and oil, and geography. Particularly interesting are articles describing the two new geological museums : the Chernyshev Central and Prospecting 
Museum at Leningrad, opened in 1931 and containing collections illustrative of the progress of the geological survey of the U.S.S.R.; and the Karpinsky Geological Museum at Moscow, opened in 1934 and containing 72,250 specimens of minerals. These are arranged in five separate collections: systematic, geochemical, genetic, crystallographic and applied. Another interesting aspect of the status of geology in the U.S.S.R. is the establishment in 1920 of the Ilmen National Park in the southern Urals for the preservation and study of the famous mineral localities of precious stones and other minerals as well as flora and fauna.

The progress made in the U.S.S.R. in the utiliza. tion of mineral wealth is described independently in a short article by V. I. Kryzhanovsky ${ }^{2}$, in which he gives a review of the achievement in the exploration and utilization of various ores. Only a few outstanding examples can be given here: the discovery of very rich iron ore at Magnitogorsk in the southern Urals, nickel and titanium in the southern Urals and Kola peninsula, molybdenum and tungsten ores in Siberia and Central Asia, bauxite at Tichvin (near Leningrad) and the Urals, tin ore (previously unknown in the U.S.S.R.) in Central Asia. There is also a description of the progress made in the prospecting and mining of gold, platinum, uranium, radium, manganese, coal and oil, borates, etc. But probably the most spectacular discoveries are those of apatite in the Kola peninsula and potash salts in the Urals, both of them of great importance in agriculture. The apatite deposits of the Kola peninsula, discovered in 1921, are the richest in the world, with an estimated reserve of 2,000 million tons. Since this discovery, a now industrial area with two new thriving towns has sprung up in a previously deserted arctic tundra. Besides apatite, a, number of other minerals were discovered in the Kola peninsula, such as nepheline, pyrrhotite, titanium ores, ores of rare elements, kyanite, garnet, etc.

The discovery of potash salts at Solikamsk in the northern Urals is no less spectacular. The reserves of sylvite at Solikamsk are estimated to be five times greater than those at Stassfurt in Germany, hitherto regarded as the richest deposit in the world, and still more deposits are being discovered as the survey progresses.

The mineral wealth of the U.S.S.R., always known to be enormous, is rapidly coming within reach of the miner and thus provides a solid foundation for an ever increasing industrialization. The contributions made by geologists and miners to the defence of their country are thus inestimable. S. I. TomkeIFFr.

" "The Progress of Geological and Geographical Sciences in the U.S.S.R during Twenty-five Years". In Russian. Edited by V. A. Obruchev (Moscow-Leningrad: Academy of Sciences of the U.S.S.R., 1943.)

${ }^{2}$ Kryzanovsky, V. I. "Les fossiles et la defence de l'URSS", Bull. Acad. Sci. URSS., Ser. Geol., No. 6, 3 (1941).

\section{CHEMISTRY IN RELATION TO MEDICINE}

$\mathrm{I}^{\mathrm{N}}$ I a recent lecture before the Royal Institute of Chemistry* on some recent advances in chemistry in relation to medicine, $D$. H. Hey gives an interesting and coneise account of the astonishing contributions which have been made in this field during the

* "Some Recent Advances in Chemistry in Relation to Medicine". By Dr. D. H. Hey. Pp. 24. (London: Royal Institute of Chemistry, 1944. last ten years. The beginning of this century saw the introduction of the first therapeutic compound of major importance which had been made to the chemist's design, namely, aspirin, first made in 1899 . At the present rate of progress, Dr. Hey suggests, the present major diseases and scourges of mankind will be completely controlled well before the end of this century. This will seem to some medical men an optimistic prophecy; but certainly recent work gives every reason to hope for its realization. One difficulty, however, is that the human talent which slays these dragons so rapidly discovers almost as quickly new causes of disease which defeat existing remedies; and although we may banish the major scourges, we should give equal attention to the minor ones, some of which cause incalculable unhappiness and economic loss and are untouched by our most efficient therapeutic compounds - the 'common cold', for example.

Dr. Hey deals with the sulphonamides, the amidines, the antibiotics (such as penicillin) and the steroid hormones (testosterone, cestradiol and progesterone). "It is no exaggeration to say that the new sulphonamide derivatives prepared during the last seven or eight years can be numbered by the thousand, but the vast majority of these have never been tested in vivo". The author explains how the chemist has juggled with the sulphonamide hydrogen atoms in the sulphonamide molecule to produce sulphapyridine, sulphathiazole and other compounds which are now being widely used, and he discusses the properties and bacteriostatic actions of these.

The history of the development of the amidines illustrates the tortuous paths by which final success is sometimes attained. Hey traces the origin of the work on the amidines to an early observation by Koch on parathyroid tetany. Methylguanidine was found in the urine of animals suffering from this, and it was found that administration of methylguanidine or of guanidine caused a fall in blood sugar. Guanidine compounds of greater activity but less toxicity were then sought out, and synthalin and synthalin B were introduced for the oral treatment of diabetes; but they caused too much damage to the liver. It was also found that trypanosomes consume, in artificial cultures, large quantities of glucose, and it was hoped that synthalin, by reducing the blood sugar, would interfere with the development of the trypanosomes and so would be useful for the treatment of sleeping sickness. Lourie and Warrington Yorke found that it did affect the trypanosomes, but not because it reduced the blood sugar but because it was trypanocidal, while insulin was not. This led to the discovery of less toxic drugs of this type, some of which have been tried for the treatment of trypanosomiasis and also, by virtue of their antibacterial action, for the treatment of burns and wounds. The Lancet (796, June 17, 1944), for example, discusses the use of propamidine $\left(4: 4^{\prime}\right.$-diamidinodiphenoxypropane) for the treatment of sepsis in burns and wounds, pointing out that the work of F. R. Selbie and J. MeIntosh (J. Path. and Bact., $55,477 ; 1943)$ and of J. W. Allen, F. Burgess and G. R. Cameron (ibid., 56, 217; 1944) and of others indicates that the toxicity of this drug requires care in its use and selection of suitable cases. The British Medical Journal (725, May 27, 1944) discusses the relative advantages and disadvantages of the diamidines and antimonial compounds for the treat. ment of kala-azar and gives further references to the literature about them. 